\title{
Mature Sweet Cherries Have Low Turgor
}

\author{
Moritz Knoche ${ }^{1}$, Eckhard Grimm, and Henrik Jürgen Schlegel \\ Institute for Horticultural Production Systems, Fruit Science Section, Leibniz University Hannover, \\ Herrenhäuser Straße 2, 30419 Hannover, Germany
}

\begin{abstract}
ADDITIONAL INDEX WORDS. cracking, exocarp, osmotic potential, pressure, Prunus avium, strain, transpiration, water potential, water uptake

Abstract. The pressure inside a mature sweet cherry (Prunus avium L.) fruit is thought to be an important factor in rain cracking. However, to our knowledge, this pressure has never been quantified directly. The objectives of this study are to quantify: 1) the cell turgor $\left(\Psi_{P}^{\text {cell }}\right)$ in fruit using a cell pressure probe $(\mathrm{CPP})$ and a vapor pressure osmometer (VPO); and 2) the tissue pressure in a fruit $\left(\Psi_{P}^{\text {fruit }}\right)$ using both a fruit pressure probe (FPP) and a compression-plate technique (CP). The value of $\Psi_{P}^{\text {cell }}$ in mesocarp cells of mature sweet cherry fruit averaged 28.1 $\mathrm{kPa}$ in 'Samba' and $17.5 \mathrm{kPa}$ in 'Sam' at depths below the fruit surface between 200 and $400 \mu \mathrm{m}$. A $\Psi_{P}^{\text {cell }}$ (range 38 to $64 \mathrm{kPa}$ for different cultivars) calculated from the tissue water potential ( $\Psi^{\text {tissue }}=-2968$ to $\left.-4035 \mathrm{kPa}\right)$ and the osmotic potential $\left(\Psi_{\Pi}^{\text {fruit }}\right)\left(\Psi_{\Pi}^{\text {fruit }}=-3020\right.$ to $\left.-4116 \mathrm{kPa}\right)$ of excised mesocarp discs as determined by VPO was of the same order of magnitude as that by CPP. Similar low $\Psi_{P}^{\text {fruit }}$ values were obtained by FPP (range 8.0 to $11.8 \mathrm{kPa}$ across cultivars). The $\Psi_{P}^{\text {fruit }}$ were consistently lower than the $\Psi_{P}^{\text {cell }}$ values measured by CPP or by VPO. The $\Psi_{P}^{\text {fruit }}$ value in the mesocarp increased slightly with increasing depth below the surface. However, $\Psi_{P}^{\text {fruit }}$ was always negligible (e.g., 'Samba' $\Psi_{P}^{\text {fruit }}=10 \mathrm{kPa}$ ) compared with either $\Psi_{\Pi}^{\text {fruit }}$ ('Samba' $\Psi_{\Pi}^{\text {fruit }}=-2395 \mathrm{kPa}$ ) or calculated water potential $\left(\Psi^{\text {fruit }}\right.$ ) ('Samba' $\left.\Psi^{\text {fruit }}=-2385 \mathrm{kPa}\right)$. When subjecting intact fruit to $\mathrm{CP}$, linear relationships were obtained between the forces applied and the resulting aplanation areas. The $\Psi_{P}^{\text {fruit }}$ values obtained by $C P$ (range in sweet cherry 18.4 to $36.1 \mathrm{kPa}$ ) were somewhat larger than the $\Psi_{P}^{\text {fruit }}$ values obtained by FPP (range in sweet cherry 8.0 to $11.8 \mathrm{kPa}$ ). Incubating fruit for up to $7.5 \mathrm{~h}$ in deionized water or for up to $96 \mathrm{~h}$ in air enclosed above dry silica gel had no measurable effects on $\Psi_{P}^{\text {fruit }}$. The low $\Psi_{P}^{\text {cell }}$ and the low $\Psi_{P}^{\text {fruit }}$ values are not unique to sweet cherry. Values of the same order of magnitude were obtained also in mature sour cherry (Prunus cerasus L.), european plum (Prunus domestica L.), grape (Vitis vinifera L.), gooseberry (Ribes uva-crispa L.), red currant (Ribes rubrum L.), black currant (Ribes nigrum L.), blueberry (Vaccinium corymbosum L.), and tomato (Solanum lycopersicum L.). Possible explanations for the very low values of $\Psi_{P}^{\text {cell }}$ and $\Psi_{P}^{\text {fruit }}$ are discussed.
\end{abstract}

Rain-induced cracking severely limits production of many soft-textured, drupe, and berry fruits. Sweet cherry is a prominent example of the former (Christensen, 1996). Cracking is commonly assumed to result from increased fruit turgor, caused by osmotic water uptake through the wetted fruit skin or the pedicel during and after precipitation or heavy dew (Considine and Kriedemann, 1972; Measham et al., 2009; Sekse, 1995; Sekse et al., 2005). As a consequence of water uptake, fruit volume and, hence, skin surface area must increase. It is believed that as the skin surface area increases, the fruit will crack because the skin area increase exceeds the natural limit of its extensibility. The associated pressure immediately before cracking is referred to as the critical turgor pressure (Considine and Kriedemann, 1972; Measham et al., 2009).

In discussions of plant water relations, cell turgor pressure is usually understood in terms of the sensible pressure in the semifluid protoplast when it is constrained within a taut cell wall. Cell turgor is usually (but not always) defined relative to atmospheric pressure. In this explanation of fruit cracking, the term "turgor" is used analogously to this to refer to the tissue pressure in a soft fruit's semifluid parenchymatous mesocarp when it is constrained within a taut fruit skin. That is, the entire

Received for publication 12 Aug. 2013. Accepted for publication 15 Oct. 2013. This research was funded in part by a grant from the Deutsche Forschungsgemeinschaft.

We thank Friederike Schroeder and Simon Sitzenstock for technical assistance and Drs. Sandy Lang and Michael Blanke for very helpful comments on an earlier version of the manuscript.

${ }^{1}$ Corresponding author. E-mail: moritz.knoche@obst.uni-hannover.de. fruit is considered to behave in a way analogous to a single plant cell.

Although the critical turgor pressure model seems to offer a logical conceptual framework for explaining fruit cracking, it has not, to our knowledge, been critically examined and the evidence supporting it is mostly circumstantial or indirect.

The objectives of our present study therefore were 1) to quantify $\Psi_{P}^{\text {fruit }}$ and $\Psi_{P}^{\text {cell }}$ in mature sweet cherry fruit using pressure probes, water vapor pressure osmometry, and compression plates; and 2) to establish the effects of water uptake and water loss on $\Psi_{P}^{\text {fruit }}$.

\section{Materials and Methods}

Plant material. Fruits of uniform size and color were harvested at commercial maturity from greenhouse-grown sweet cherries ('Kordia', 'Korvic', 'Sam', 'Samba', 'Sweetheart', 'Staccato') and sour cherries ('Ungarische Traubige') both grafted on 'Gisela 5' rootstocks $(P$. cerasus $\times$ Prunus canescens Bois) or from field-grown european plum ('Doppelte Hauspflaume' grafted on Prunus insitia L. 'St. Julien A'), gooseberry ('Invicta'), red currant ('Rovada'), black currant ('Titania'), and blueberry ('Elliott') at the Horticultural Research Station in Sarstedt (lat. 52 $14^{\prime}$ N, long. $9^{\circ} 49^{\prime}$ E) or the Herrenhausen campus garden of the Leibniz University Hannover (lat. $52^{\circ} 23^{\prime} \mathrm{N}$, long. $9^{\circ} 42^{\prime} \mathrm{E}$ ). Grapes were obtained from a commercial vineyard at Gleidingen ['Fanny' (lat. 52 ${ }^{\circ} 16^{\prime} \mathrm{N}$, long. $9^{\circ} 42^{\prime}$ E)] or an experimental vineyard at Neustadt/ Weinstraße ['Riesling' (lat. $49^{\circ} 22^{\prime} \mathrm{N}$, long. $8^{\circ} 11^{\prime}$ E)]. Tomato ('Micro-Tom') was cultivated in a greenhouse on the 
Herrenhausen campus garden. Fruit were processed on the day of sampling. The only exceptions were the 'Riesling' grapes that were processed within $34 \mathrm{~h}$ of sampling.

QuANTIFYING $\Psi_{\boldsymbol{P}}^{\text {cell }}$ AND $\Psi_{\boldsymbol{P}}^{\text {fruit }}$ USING PRESSURE PROBES. The pressure probe is a device for investigating plant water relations. For detailed descriptions of the various techniques involved and modes of operation, see Steudle (1993). The pressure probes used in our study were the cell pressure probe and the root pressure probe as described by Steudle (1993). The latter probe may also be used to quantify the $\Psi_{P}^{\text {fruit }}$ in detached fruit (e.g., Lang and Düring, 1990) and is therefore referred to here as the fruit pressure probe. The functional principles of the CPP and FPP are identical. Both instruments comprise a drawn glass capillary (tip diameter 30 to $60 \mu \mathrm{m}$ for the CPP and 150 to $250 \mu \mathrm{m}$ for the FPP) filled with silicone oil (AS 4; Wacker Chemie, München, Germany) free of air bubbles and connected to a pressure sensor (26PCGFA6D; Honeywell Sensing and Control, Golden Valley, MN). When inserting the capillary of the CPP into a cell or that of the FPP into a fruit and establishing hydraulic continuity with the cell's symplast (CPP), or the fruit flesh (FPP), the pressure inside the probe equilibrates with that in the cell (CPP), or fruit (FPP). In CPP experiments, successful insertions of the capillary are determined under a horizontalaxis microscope when a meniscus becomes visible in the capillary between the aqueous cell contents (forced into the capillary by cell pressure) and the silicone oil. This insertion is not associated with a marked change in pressure (Fig. 1). To make a measurement, the meniscus is pushed back usually after 10 to $15 \mathrm{~s}$ to its presumed initial position at the tip of the

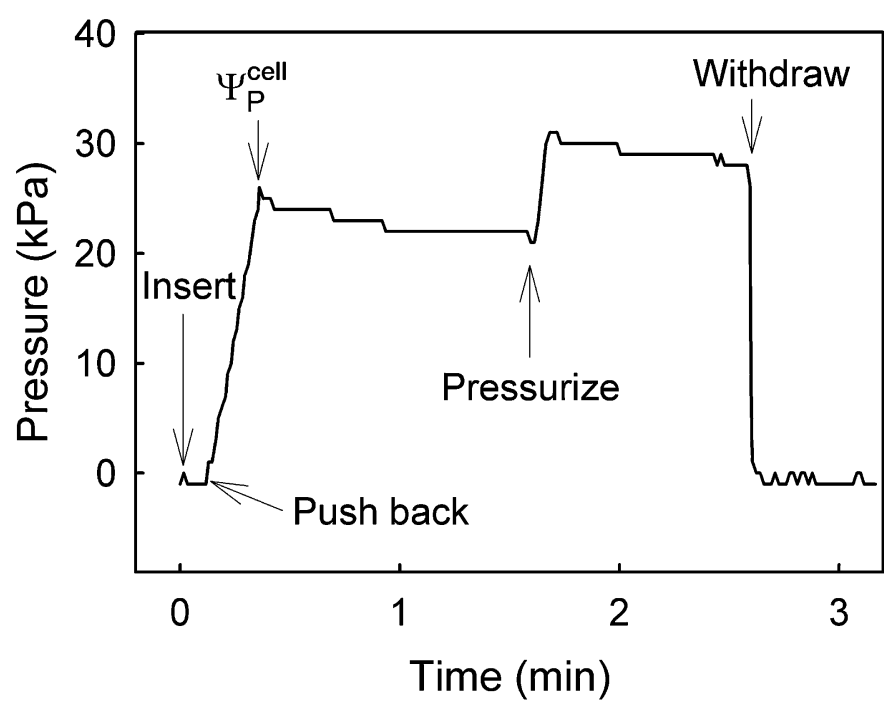

Fig. 1. Typical time course of change in pressure during a measurement of cell turgor $\left(\Psi_{P}^{\text {cell }}\right)$ of a single cell in the outer mesocarp of a mature 'Samba' sweet cherry fruit using the cell pressure probe (CPP). The glass capillary is inserted into a cell at 0 min ("Insert") under a horizontal axis microscope. The juice/ silicone oil meniscus is pushed back ("Push back") to its original position at the tip of the capillary at $0.15 \mathrm{~min}$ (equivalent to $10 \mathrm{~s}$ ). This push back restores the initial cell volume and is associated with an increase in pressure. The peak pressure recorded in the oil after the push back represents the $\Psi_{P}^{c e l l}$. Thereafter, the pressure typically decreases slightly and then remains constant. At $\approx 1.5$ min, the CPP is pressurized again ("Pressurize") to control for plugging of the capillary by injecting silicone oil into the cell. After an instantaneous transient increase, the pressure re-equilibrates within $\approx 1 \mathrm{~min}$ and then drops to the ambient pressure (initial before the test) as the capillary is withdrawn from the cell at $\approx 2.5 \min$ ("Withdraw"). capillary by careful displacement of the oil. When the meniscus is in this position, the initial volume of the punctured cell is approximately restored. The push back is associated with an increase in pressure up to a peak pressure. Thereafter, the pressure decreases slightly approaching an asymptote at a slightly lower level (Fig. 1). The peak pressure recorded in the oil is deemed to represent the value $\Psi_{P}^{\text {cell }}$. Peak pressure $\left(P^{\text {peak }}\right)$ and the pressure of the asymptote $\left(P^{\text {asymptote }}\right)$ are very closely and linearly related $\left[P^{\text {asymptote }}(\right.$ kilopascals $)=0.79( \pm 0.007) \times P^{\text {peak }}($ kilopascals $) ; r^{2}=$ $0.99, P=0.0001, \mathrm{n}=82]$. Preliminary experiments established that there is no significant difference $(P=0.55)$ between the peak pressure (Stage II 'Regina': $234 \pm 40 \mathrm{kPa}$ ) and the mean pressure (Stage II 'Regina': $273 \pm 30 \mathrm{kPa}$ ) recorded when the meniscus is held just above the fruit surface (E. Grimm, unpublished data). For this experiment, Stage II fruit was selected, because at this developmental stage, the $\Psi_{P}^{\text {cell }}$ is markedly higher than at the mature stage (E. Grimm, unpublished data).

When using the FPP, insertion of the capillary is associated with an increase in the pressure signal (Fig. 2A). Unlike CPP measurements, a meniscus is not usually detectable. In this case an equilibrium pressure is recorded as the $\Psi_{P}^{\text {fruit }}$ with no further manipulation. Given the tiny displacement volume of the probe apparatus relative to that of the whole fruit, this seems reasonable (additional care is clearly more important for the cell probe where the relative volumes are more similar). In our FPP measurements on tomato, a meniscus was usually visible in the capillary so, in this case, we were able to force this back to the tip before reading the equilibrium pressure.

Occasionally, the capillaries of the CPP or FPP became plugged or the seal between the capillary and cell wall (CPP) or between the capillary and fruit skin (FPP) became leaky. Both occurrences resulted in an obviously erroneous result. Plugging was easily recognized by a rapid pressure increase, whereas leakage was easily recognized by a continuing pressure decrease. Any such data were excluded from our analyses. After a pressure measurement, the CPP or FPP was withdrawn and this was always accompanied by a decrease in pressure to that of the ambient air recorded just before capillary insertion. The occasional absence of a pressure decrease on withdrawal was also indicative of plugging.

The $\Psi_{P}^{\text {cell }}$ and $\Psi_{P}^{\text {fruit }}$ were quantified in sweet cherry and in selected drupe and berry crops using the CPP and FPP as described previously. The number of replications ranged from 12 to 46 successful insertions per species (mean 26 insertions) for determining $\Psi_{P}^{\text {cell }}$ by CPP and from six to 30 per species (mean 14 insertions) for determining $\Psi_{P}^{\text {fruit }}$ by FPP.

The possibility of a radial gradient of $\Psi_{P}^{\text {fruit }}$ within a sweet cherry was investigated in mature fruit of 'Sam' and 'Samba'. The FPP was inserted at stepwise depth increments. The number of replications was 10 . To relate $\Psi_{P}^{\text {fruit }}$ to the $\Psi_{\Pi}^{\text {fruit }}$ and the water potential of the fruit $\left(\Psi^{\text {fruit }}\right)$, a radial block of tissue (cross-section $\approx 2 \times 2 \mathrm{~mm}$, length $\approx 11 \mathrm{~mm}$ ) extending from pit (endocarp) to skin (exocarp) was excised from the same batch of fruit. This block was divided transversely into five roughly equal parts. Each part was immediately crushed onto the sample holder of a water vapor pressure osmometer (VAPRO $^{\circledR} 5520$; Wescor, Logan, UT) and the $\Psi_{\Pi}^{\text {fruit }}$ of its juice determined. In analogy to the cell's water potential equation (Taiz and Zeiger, 1991), the $\Psi^{\text {fruit }}$ was calculated from $\Psi^{\text {fruit }}=$ $\Psi_{\Pi}^{\text {fruit }}+\Psi_{P}^{\text {fruit }}$.

QuANTIFYING $\Psi_{\boldsymbol{P}}^{\text {cell }}$ BY VPO. The $\Psi_{\boldsymbol{P}}^{\text {cell }}$ was also quantified using VPO (VAPRO ${ }^{\circledR}$ 5520) and tissue discs excised from the 

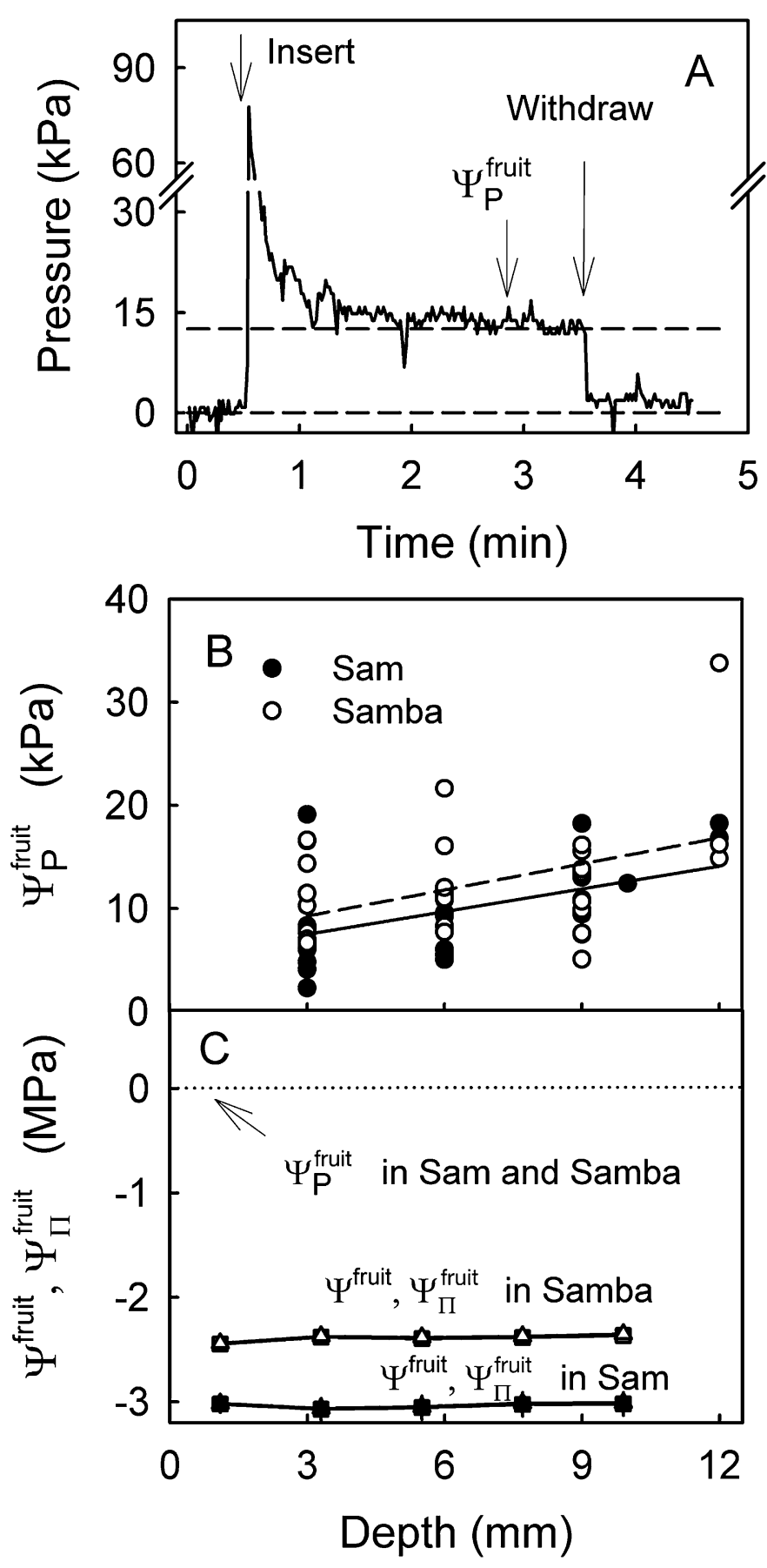

Fig. 2. (A) Typical time course of change in pressure inside a mature 'Sam' sweet cherry fruit during a measurement of the whole fruit pressure $\left(\Psi_{P}^{\text {fruit }}\right)$ using the fruit pressure probe (FPP). A glass capillary is inserted into the fruit $\approx 5 \mathrm{~mm}$ below the epidermis at $0.5 \mathrm{~min}$. On insertion, the pressure instantaneously increases. After a transient peak, the pressure equilibrates at $\approx 2.5 \mathrm{~min}$. The equilibrium pressure as indicated by the arrow represents the $\Psi_{P}^{\text {fruit }}$. At $\approx 3.5$ min, the capillary is withdrawn from the fruit and the pressure equilibrates again with the ambient pressure. (B) Change of $\Psi_{P}^{\text {fruit }}$ of mature 'Sam' and 'Samba' sweet cherry as depth of insertion increases. The insertion depth represents the distance between the tip of the capillary of the FPP and the fruit surface. The regression equations were: $\Psi_{P}^{\text {fruit }}$ (kilopascals) $=5.28( \pm 1.88)+0.73( \pm 0.27)$ depth (millimeters), $r^{2}=0.22, P=0.01, \mathrm{n}=29$ for 'Sam' and $\Psi_{P}^{\text {fruit }}$ (kilopascals) $=$ $6.73( \pm 2.54)+0.84( \pm 0.35)$ depth (millimeters), $r^{2}=0.19, P=0.02, \mathrm{n}=27$ for 'Samba'. (C) Osmotic potential $\left(\Psi_{\Pi}^{\text {fruit }}\right)$ and calculated water potential $\left(\Psi^{\text {fruit }}\right)$ for mature 'Sam' and 'Samba' at varying depth. Data for $\Psi_{P}^{\text {fruit }}$ were redrawn from B. The $\Psi^{\text {fruit }}$ was calculated as the sum of $\Psi_{\Pi}^{\text {fruit }}$ of expressed juice plus the $\Psi_{P}^{\text {fruit }}$ for 'Sam' and 'Samba', respectively. Note that as a result of the very low $\Psi_{P}^{\text {fruit }}$, the symbols for $\Psi^{\text {fruit }}$ and $\Psi_{\Pi}^{\text {fruit }}$ are superimposed in both cultivars. sweet cherry mesocarp. Briefly, cylinders of mesocarp (diameter $8 \mathrm{~mm}$ ) were excised from the cheeks of mature 'Kordia', 'Sweetheart', and 'Staccato' sweet cherries using a medical biopsy punch (BP-80F; Kai Industries, Gifu, Japan). Discs ( $\approx 2 \mathrm{~mm}$ thick) were cut from these cylinders with a razor blade. These were gently blotted using soft tissue paper (7216; Kimberly-Clark, Reigate, U.K.) and placed within $60 \mathrm{~s}$ of excision on the circular sample holder $(9.5 \mathrm{~mm}$ diameter, $4.5 \mathrm{~mm}$ deep) of the osmometer. The water potential $\left(\Psi^{\text {tissue }}\right)$ was read 15 min after closure of the sample chamber when equilibrium reading had been reached. Next, the sample chamber was reopened, the cells destroyed by crushing with a glass rod, the chamber reclosed, and $\Psi^{\text {tissue }}$ remeasured. The water potential reading thus obtained represented the $\Psi^{\text {tissue }}$ after release of the $\Psi_{P}^{\text {cell }}$ component. Preliminary experiments established that there was no difference between a $\Psi_{\Pi}^{\text {fruit }}$ measured with $(-3449 \pm$ $118 \mathrm{kPa}$ ) and without cell walls ( $-3464 \pm 123 \mathrm{kPa}$ for juice only). Therefore, the $\Psi_{\Pi}^{\text {fruit }}$ results reported here are those determined for crushed discs including the cell walls.

Initial experiments were carried out to establish the time course of equilibration within the osmometer chamber of the water vapor pressure above the sample with the sample's $\Psi^{\text {tissue }}$. The number of sample replications was five. Thereafter, $\Psi^{\text {tissue }}$ and $\Psi_{\Pi}^{\text {fruit }}$ were quantified as described previously and $\Psi_{P}^{\text {cell }}$ was calculated for mature 'Kordia', 'Sweetheart', and 'Staccato' cherries using 10 fruit replications per cultivar.

Quantifying $\Psi_{\boldsymbol{P}}^{\text {fruit }}$ using The CP. The CP as described by Bernstein and Lustig (1981) was used to quantify the $\Psi_{P}^{\text {fruit }}$ of sweet cherry fruit. Briefly, a fruit was positioned between two glass plates in a universal material testing machine $(Z \quad 0.5$; Zwick Roell, Ulm, Germany) equipped with a 500-N-force transducer (KAF-TC; Zwick Roell). The lower pressure plate was custom-made from translucent etched glass such that the aplanation area of the fruit could be photographed through it from below using a digital camera (Altra 20; Olympus Europa, Hamburg, Germany). To enhance contrast, the fruit surface was smeared with a thin coat of silicone grease. Unless specified otherwise, the cheek of the fruit opposite the suture faced the camera. Before initiation of the test, the compression plate was brought into contact with the fruit by applying a force of $0.05 \mathrm{~N}$. The $\Psi_{P}^{\text {fruit }}$ was determined by stepwise loading of the fruit with increasing force. After each force step, the position of the compression plates was held constant and a gradual decrease in force was observed as a result of gradual deformation (viscoelastic and/or plastic) of the fruit, which was followed over time until an asymptote was approached. Digital photographs were taken at selected time intervals and the aplanation areas between fruit and plate quantified by image analysis (Software Cell ${ }^{\wedge} \mathrm{P}$; Olympus Soft Imaging Solution, Münster, Germany). The $\Psi_{P}^{\text {fruit }}$ (megapascals) was calculated as the slope of a linear regression line fitted through a plot of force, $F$ (Newtons) vs. aplanation area $A$ (square millimeters).

The time course of change in force, aplanation area, and $\Psi_{P}^{\text {fruit }}$ was established in mature fruit of 'Sam'. Individual fruit were loaded stepwise with $0,1,2,4,6$, and $8 \mathrm{~N}$ and the changes in force vs. aplanation area at each force were followed over a 10-min period. The $\Psi_{P}^{\text {fruit }}$ was calculated as described previously. The number of fruit replications was five.

The effect of orientation of the sweet cherry fruit during the test on $\Psi_{P}^{\text {fruit }}$ was studied. Orientation was varied by placing mature 'Sam' fruit between the plates in the following orientations: suture up, suture down, or suture to the side (in 
all three orientations, the fruit's pedicel/stylar-scar axis was horizontal). Compression tests were performed by stepwise increasing force to $0.5,1,2,4$, and $6 \mathrm{~N}$. Aplanation area was recorded $5 \mathrm{~min}$ after applying each force when an approximate equilibrium had been reached. The number of fruit replications was seven.

EFFECTS OF WATER UPTAKE OR WATER LOSS ON $\Psi_{P}^{\text {fruit }}$. The effect of water uptake on $\Psi_{P}^{\text {fruit }}$ was established in mature 'Sweetheart' sweet cherries using the FPP. Briefly, pedicels were cut flush with the receptacle and the fruit incubated in deionized water for up to $7.5 \mathrm{~h}$. There was no silicone sealant applied to the pedicel fruit juncture. Water uptake was determined as the increment in fruit mass during incubation (fruit mass after, minus before) (Weichert et al., 2004). After water uptake, $\Psi_{P}^{\text {fruit }}$ was quantified by FPP as described previously. The experiment was carried out on a total of 29 fruit.

The effect of water loss and of water uptake on $\Psi_{P}^{\text {fruit }}$ was studied in mature 'Regina'. The pedicels were cut flush with the receptacle. The cut surface of the pedicel and the remaining gap between the receptacle and fruit, subsequently referred to as the pedicel/fruit junction, was sealed with silicone sealant (3140 RTV coating; Dow Corning, Midland, MI) to exclude any water loss/gain around the pedicel/fruit junction (Beyer et al., 2002). After curing at ambient temperature for a minimum of $3 \mathrm{~h}$, fruit were incubated above dry silica for $0,24,48$, and $96 \mathrm{~h}$. Water loss resulting from fruit transpiration was quantified gravimetrically. The $\Psi_{P}^{\text {fruit }}$ was quantified on a subsample $(\mathrm{n}=59)$ of fruit using the FPP. A second subsample of fruit $(n=55)$ was subjected to water-uptake experiments after the transpiration step. This fruit was incubated in deionized water. Water uptake was determined gravimetrically after immersion for $0,0.75$, and $1.5 \mathrm{~h}$ followed by careful blotting. Rates of uptake were calculated on an individual fruit basis from the slope of a regression line of a plot of cumulative fruit mass vs. time. Coefficients of determination averaged $r^{2}=0.99$.

Data Analysis. Data were subjected to analysis of variance (ANOVA). ANOVA, multiple comparisons of means, correlation, and regression analyses were carried out using Proc CORR, Proc GLM, and Proc REG (SAS Version 9.1.3; SAS Institute, Cary, NC). Data in tables and in Figures 2C, 3, and 4D are presented as means \pm SE. In all other figures, symbols represent data from individual fruit.

\section{Results}

Determining $\Psi_{\boldsymbol{P}}^{\text {cell }}$ BY CPP AND VPO. When the capillary of the CPP was inserted into the outer mesocarp of mature sweet cherry fruit, the pressure signal usually remained constant while some cell content was forced into the capillary by cell turgor (Fig. 1). Under the horizontal-axis microscope, a meniscus was visible between the red-colored cell contents and the silicone oil in the capillary. This meniscus is indicative of a successful insertion. Approximately 10 to $15 \mathrm{~s}$ after insertion, the meniscus was pushed back toward its initial position at the tip of the capillary by displacing a volume of silicone oil using the CPP's micrometer screw. The push back was associated with an increase in the CPP system pressure and re-established the initial volume and pressure $\left(\Psi_{P}^{\text {cell }}\right)$ of the punctured mesocarp cell (Fig. 1). Thereafter, the system pressure gradually decreased and approached an asymptote at a slightly lower level. A measurement of $\Psi_{P}^{\text {cell }}$ was judged successful if the following two conditions were met: 1) repressurizing the cell during the

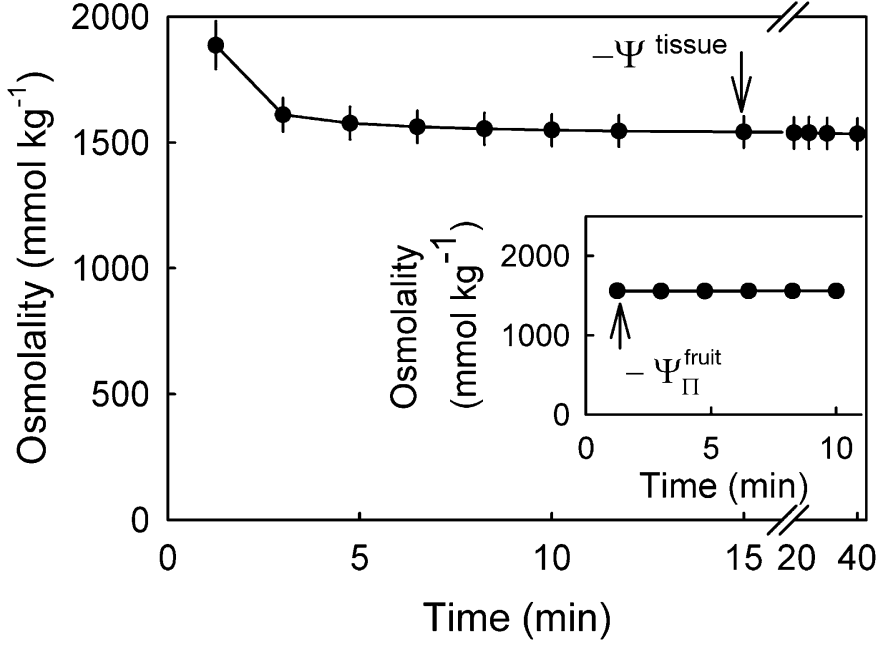

Fig. 3. Time course of equilibration of excised mesocarp discs (main graph) and of juice extracted from the discs (inset) in a water vapor pressure osmometer. At time zero, the sample chamber was closed and the change in apparent osmolality beginning at $80 \mathrm{~s}$ monitored over time. The mesocarp discs were excised and the juice extracted from 'Kordia' sweet cherry fruit. The arrows indicate the time required for equilibrating samples. At these times, the osmolality reading represented the water potential of the mesocarp disc $\left(\Psi^{\text {tissue }}\right)$ and the osmotic potential of the juice (inset; $\Psi_{\Pi}^{\text {fruit }}$ ).

push back must increase the system pressure signal, which must equilibrate (asymptote) at an elevated level over a period of typically 1 to 2 min (Fig. 1 ); and 2) when the capillary was later withdrawn from the fruit, the CPP system pressure must drop to the same level as immediately before insertion. Occasional plugging of the capillary was detectable as a departure from this regular pattern. Such measurements were excluded from the analyses. Outer mesocarp $\Psi_{P}^{\text {cell }}$ values averaged $28.1 \mathrm{kPa}$ in 'Samba' and $17.5 \mathrm{kPa}$ in 'Sam' (Table 1). Meanwhile, $\Psi_{P}^{\text {cell }}$ of european plums, grapes, and tomatoes was somewhat higher (Table 1). In blueberries, nine of the 12 insertions yielded a $\Psi_{P}^{\text {cell }}$ value of $0 \mathrm{kPa}$. The remaining three $\Psi_{P}^{\text {cell }}$ measurements averaged $34.9 \mathrm{kPa}$, giving an overall average $\Psi_{P}^{\text {cell }}$ value of $8.7 \mathrm{kPa}$ (Table 1).

When placing excised tissue blocks in the sample chamber of a VPO, the apparent osmolality increased with time, reaching an equilibrium $\approx 6 \mathrm{~min}$ after closure of the sample chamber (Fig. 3 ). From this time onward, the readout remained constant and the osmolality displayed corresponded reliably to the $\Psi^{\text {tissue }}$. Juice extracted from the tissue samples equilibrated within $80 \mathrm{~s}$, yielding an estimate of the $\Psi_{\Pi}^{\text {fruit }}$ within the standard equilibration time of the instrument (Fig. 3, inset). Across the three sweet cherry cultivars, the indirect $\Psi_{P}^{\text {cell }}$ measurement, estimated by subtracting $\Psi_{\Pi}^{\text {fruit }}$ from $\Psi^{\text {tissue }}$, averaged $50 \mathrm{kPa}$ (Table 2).

DETERMINING $\Psi_{\boldsymbol{P}}^{\text {fruit }}$ BY FPP AND CP. Inserting the capillary of the FPP in the mesocarp of sweet cherry and other drupe and berry fruit yielded changes of pressure with time, similar to those with the CPP (Fig. 2A). Usually an equilibrium value of $\Psi_{P}^{\text {fruit }}$ was attained within $3 \mathrm{~min}$. In fruit of nearly all species, an oil/water meniscus was not detectable. The exception was tomato, in which a meniscus was visible between the aqueous juice of the fruit and the silicone oil in the capillary. This meniscus was pushed back as described previously by turning the micrometer plunger. On withdrawal of the capillary from the fruit, the pressure declined to the level just before insertion 

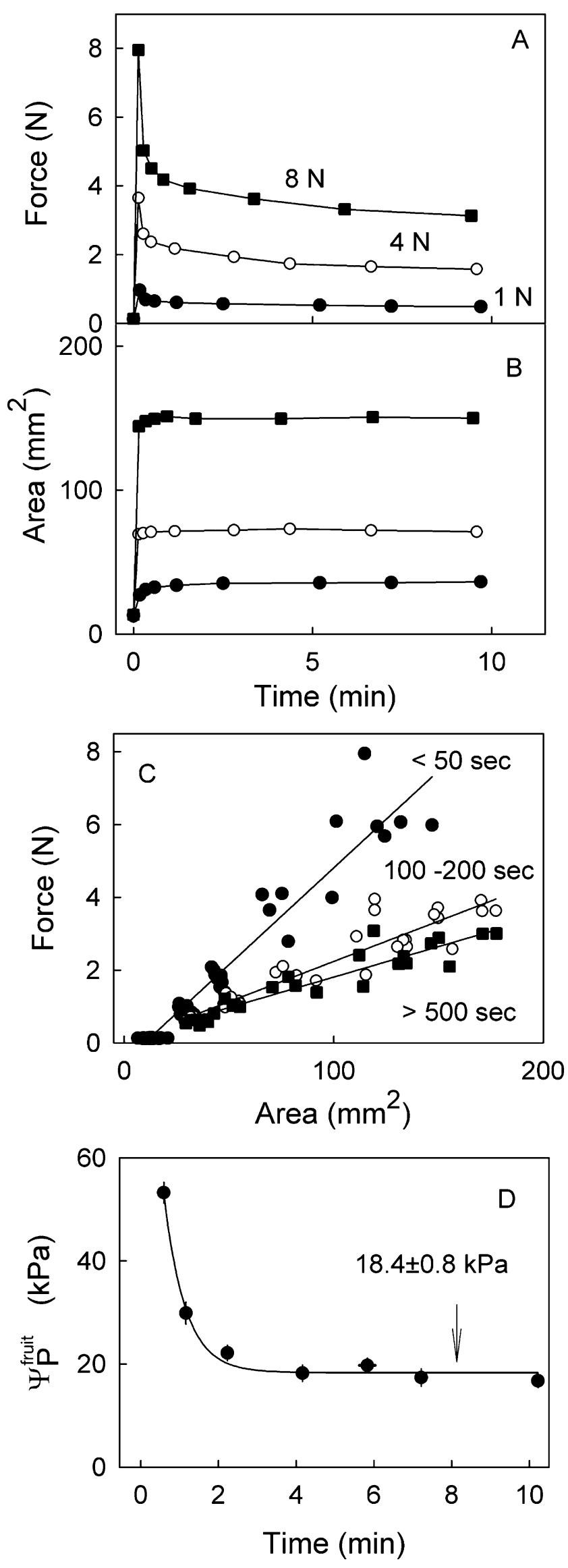

indicating that there was no plugging of the capillary. Across cultivars and species, the values of $\Psi_{P}^{\text {fruit }}$ as determined by FPP were of the same order of magnitude as those of $\Psi_{P}^{\text {cell }}$ by CPP or VPO but values were consistently lower (Table 1).

Increasing the depth from 1.1 to $9.9 \mathrm{~mm}$ within the 'Sam' and 'Samba' sweet cherry mesocarps to which the FPP was inserted slightly increased the measured $\Psi_{P}^{\text {fruit }}$ value in both cultivars, but only by $\approx 6.5$ and $7.4 \mathrm{kPa}$, respectively (Fig. 2B).

There was no detectable radial gradient in measured $\Psi_{\Pi}^{\text {frrit }}$ in the mesocarp of either 'Sam' or 'Samba' sweet cherry fruit and, hence, in the calculated values of $\Psi_{\text {fruit }}^{\text {fru }}$ Because the $\Psi_{P}^{\text {frit }}$ averaged only $0.3 \%$ and $0.5 \%$ of the $\Psi_{\Pi}^{\text {fruit }}$ of the juice of 'Sam' and 'Samba' fruit, respectively, we can infer that the value of $\Psi_{\Pi}^{\text {frrit }}$ must have equaled (or been very close to) that of $\Psi$. Furthermore, when plotting $\Psi_{P}^{\text {fruit }}, \Psi_{\Pi}^{\text {fruit }}$, and $\Psi^{\text {fruit }}$ on the same $y$-scaling, the values of $\Psi_{\Pi}^{\text {fruit }}$ and $\Psi^{\text {fruit }}$ were more or less superimposed for any cultivar or species and the gradient in $\Psi_{P}^{\text {fruit }}$ was not discernable (Fig. 2C).

The compression plate test for determining $\Psi_{P}^{\text {fruit }}$ yielded the relationships shown in Figure 4A-D. When applying a 1-, 4-, or $8-\mathrm{N}$ force to the fruit and holding the position of the compression plates constant after peak force was reached, the force decreased exponentially with time (Fig. 4A), whereas the aplanation area of the fruit increased approaching an asymptote (Fig. 4B). The changes in force and aplanation area during the hold periods were larger at $8 \mathrm{~N}$ than at 4 or $1 \mathrm{~N}$ (Fig. 4A-B). Plotting pairs of values for force vs. aplanation area yielded essentially linear relationships (mean $r^{2}=0.891, P=0.001$ ) in which the slopes depended on the elapsed time of the measurement after reaching peak force (Fig. 4B-C). The decrease in slope with increasing time resulted from viscoelastic and/or plastic deformation of the fruit as indexed by the decrease in force and the increase in aplanation area (Fig. 4A-C). Plotting this slope vs. the time for deformation revealed that within $\approx 3$ min of the fruit being loaded, the slope of the force/area relationship had reached a steady state and the ratio of force/ area equaled $\Psi_{P}^{\text {fruit }}$ (Fig. 4D).

The $\Psi_{P}^{\text {fruit }}$ determined by CP depended on how the fruit was aligned relative to the camera (and thus to the compressive force) (Table 3). The $\Psi_{P}^{\text {fruit }}$ value was larger when the cheek opposite to the suture faced the camera and lowest when the suture faced the camera (Table 3). Orienting the fruit with the suture sideways (i.e., at $90^{\circ}$ to the force axis) resulted in an intermediate $\Psi_{P}^{\text {fruit }}$.

EFFECT OF WATER UPTAKE AND LOSS ON $\Psi_{P}^{\text {fruit }}$. Incubating sweet cherry fruit in deionized water increased their mass at a rate of $26.0( \pm 1.3) \mathrm{mg} \cdot \mathrm{h}^{-1}\left(r^{2}=0.94, P=0.001\right)$ for up to $7 \mathrm{~h}$ (Fig. 5A). There was no significant relationship between the amount of water uptake and $\Psi_{P}^{\text {fruit }}\left[\Psi_{P}^{\text {fruit }}\right.$ (kilopascals) $=10.5$ $( \pm 0.9)-0.01( \pm 0.01) \times$ uptake (milligrams per fruit); $r^{2}=0.04$, $P=0.31$ (Fig. 5B)].

Fig. 4. Representative time courses of change in force (A) and aplanation area (B) when loading a mature 'Sam' sweet cherry fruit using a universal material testing machine. Immediately after reaching the preset force threshold of 1, 4, and $8 \mathrm{~N}$, the position of the compression plates were held constant and the decrease in force and the increase in aplanation area monitored over time. (C) Relationship between force and aplanation area within $50 \mathrm{~s}$ of reaching the preset force level, between 100 and $200 \mathrm{~s}$, and more than $500 \mathrm{~s}$. The slope of the linear regression line fitted through these relationships equals the pressure inside an intact sweet cherry fruit $\left(\Psi_{P}^{\text {fruit }}\right)$. (D) Time course of change in pressure inside the fruit during the compression plate test. The arrow indicates the pressure inside the fruit at equilibrium $\left(\Psi_{P}^{\text {friit }}\right)$. 
Table 1. Turgor of cells $\left(\Psi_{P}^{\text {cell }}\right)$ of the outer mesocarp and pressure inside a fruit $\left(\Psi_{P}^{\text {fruit }}\right)$ of selected drupe and berry fruit. ${ }^{\mathrm{z}}$

\begin{tabular}{|c|c|c|c|c|c|}
\hline Fruit type & Species & Cultivar & $\begin{array}{c}\Psi_{P}^{\text {cell }} \\
\mathrm{CPP}[\mathrm{mean} \pm \mathrm{SE}(\mathrm{kPa})]\end{array}$ & $\begin{array}{c}\Psi_{P}^{\text {fruit }} \\
\text { FPP }[\text { mean } \pm \text { SE }(\mathrm{kPa})]\end{array}$ & $\begin{array}{c}\Psi_{P}^{\text {fruit }} \\
\mathrm{CP}[\text { mean } \pm \mathrm{SE}(\mathrm{kPa})]\end{array}$ \\
\hline \multirow[t]{4}{*}{ Drupe } & Sweet cherry & Korvic & $\mathrm{ND}^{\mathrm{y}}$ & $9.0 \pm 1.1$ & $27.0 \pm 1.3$ \\
\hline & & Sam & $17.5 \pm 2.2$ & $8.0 \pm 1.6$ & $18.4 \pm 0.8$ \\
\hline & Sour cherry & Ungarische Traubige & ND & $9.3 \pm 1.0$ & $16.6 \pm 0.9$ \\
\hline & European plum & Doppelte Hauszwetsche & $68.6 \pm 8.8$ & $2.2 \pm 0.5$ & $16.7 \pm 1.4$ \\
\hline \multirow[t]{6}{*}{ Berry } & Blueberry & Elliott & $8.7 \pm 4.6$ & $0.8 \pm 0.1$ & $33.6 \pm 2.3$ \\
\hline & Grape & Riesling & $95.4 \pm 14.9$ & $2.5 \pm 0.2$ & $34.2 \pm 1.2$ \\
\hline & Grape & Fanny & $133.5 \pm 15.2$ & $4.2 \pm 0.3$ & $53.4 \pm 4.4$ \\
\hline & Red Currant & Rovada & ND & $8.2 \pm 1.8$ & $27.6 \pm 1.2$ \\
\hline & Black Currant & Titania & ND & $20.6 \pm 1.8$ & $25.2 \pm 1.0$ \\
\hline & Tomato & Micro-Tom & $42.6 \pm 3.8$ & $17.6 \pm 1.1$ & $38.5 \pm 2.1$ \\
\hline
\end{tabular}

${ }^{\mathrm{z}} \Psi_{P}^{\text {cell }}$ was determined on cells of the outer mesocarp using a cell pressure probe (CPP), the $\Psi_{P}^{\text {fruit }}$ in the mesocarp using the fruit pressure probe (FPP), or the compression plate (CP). For details on the techniques, see the "Materials and Methods."

${ }^{\mathrm{y}}$ Not determined.

Table 2. Water potential $\Psi^{\text {tissue }}$, osmotic potential $\left(\Psi_{\Pi}^{\text {fruit }}\right)$, and calculated cell turgor $\left(\Psi_{P}^{\text {cell }}\right)$ of mesocarp discs excised from mature sweet cherry fruit. ${ }^{\mathrm{z}}$

\begin{tabular}{lcccc}
\hline Cultivar & Mass $[$ mean $\pm \mathrm{SE}(\mathrm{g} /$ fruit $)]$ & $\Psi^{\text {tissue }}[$ mean $\pm \mathrm{SE}(\mathrm{kPa})]$ & $\Psi_{\Pi}^{\text {fruit }}[\mathrm{mean} \pm \mathrm{SE}(\mathrm{kPa})]$ & $\Psi_{P}^{\text {cell }}[\mathrm{mean} \pm \mathrm{SE}(\mathrm{kPa})]$ \\
\hline Kordia & $12.7 \pm 0.2 \mathrm{a}^{\mathrm{y}}$ & $-4035 \pm 159 \mathrm{a}$ & $-4116 \pm 166 \mathrm{a}$ & $38 \pm 9 \mathrm{a}$ \\
Sweetheart & $11.7 \pm 0.3 \mathrm{a}$ & $-3195 \pm 99 \mathrm{~b}$ & $-3257 \pm 106 \mathrm{~b}$ & $49 \pm 9 \mathrm{a}$ \\
Staccato & $12.7 \pm 0.5 \mathrm{a}$ & $-2968 \pm 172 \mathrm{~b}$ & $-3020 \pm 182 \mathrm{~b}$ & $64 \pm 13 \mathrm{a}$ \\
Mean & $12.4 \pm 0.2$ & $-3399 \pm 118$ & $-3464 \pm 123$ & $50 \pm 6$
\end{tabular}

${ }^{\text {zThe }} \Psi_{P}^{\text {cell }}$ was calculated from $\Psi_{P}^{\text {cell }}=\Psi^{\text {tissue }}-\Psi_{\Pi}^{\text {fruit }}$.

${ }^{\mathrm{y}}$ Mean separation within columns by Tukey's Studentized range test, $P=0.05$.

Table 3. Effect of orientation of sweet cherry on the pressure inside the fruit $\left(\Psi_{P}^{\text {fruit }}\right)$ as determined by the compression plate test.

\begin{tabular}{ll}
\hline Orientation & $\Psi_{P}^{\text {fruit }}[\mathrm{mean} \pm \mathrm{SE}(\mathrm{kPa})]$ \\
\hline Suture up & $37.8 \pm 1.8 \mathrm{a}^{\mathrm{z}}$ \\
Suture down & $26.2 \pm 2.5 \mathrm{~b}$ \\
Suture side & $35.6 \pm 3.5 \mathrm{ab}$ \\
Mean & $33.2 \pm 1.9$ \\
\hline
\end{tabular}

${ }^{\mathrm{z}}$ Mean separation by Tukey's Studentized range test, $P=0.05$.

Similarly, the amount of water transpired increased linearly with time at an average rate of $15.2( \pm 0.5) \mathrm{mg} \cdot \mathrm{h}^{-1}\left(r^{2}=0.94, P=\right.$ 0.001 ; Fig. 6A) but, again, there was no significant relationship between the amount of water lost and $\Psi_{P}^{\text {fruit }}\left[\Psi_{P}^{\text {fruit }}\right.$ (kilopascals) $=$ $13.9( \pm 1.3)-1.15( \pm 1.69) \times$ transpiration (grams per fruit); $r^{2}=$ $0.01, P=0.50$ (Fig. 6B)]. Fruit that had transpired more water had lower rates of water uptake than fruit that had transpired less indicating that the rate of water uptake and the amount of water transpired were weakly and negatively correlated $[r=-0.43, P=$ 0.0012 (Fig. 6C)].

\section{Discussion}

Our results establish several important new findings. First, the four different methods used for quantifying $\Psi_{P}^{\text {cell }}$ and $\Psi_{P}^{\text {fruit }}$ yielded largely similar pressures that were markedly lower than those reported in the literature for sweet cherry fruit.

Second, manipulating the fruit's water status had essentially no effect on $\Psi_{P}^{\text {fruit }}$ regardless of whether this was achieved by transpiration (weight loss) or by water uptake (weight gain).
CoMPARING $\Psi_{\boldsymbol{P}}^{\text {fruit }}$ AND $\Psi_{\boldsymbol{P}}^{\text {cell }}$ WITH PUBLISHED DATA. Published data for $\Psi_{P}^{\text {fruit }}$ range from 1.5 to $2.1 \mathrm{MPa}$ in sweet cherry (Andersen and Richardson, 1982). Measham et al. (2009) determined critical turgor pressures at maturity for nine sweet cherry cultivars; these averaged $2.8 \mathrm{MPa}$ (range 2.0 to 3.8 $\mathrm{MPa})$. Knoche et al. (2004) calculated turgor pressures ranging from 0.55 to $0.77 \mathrm{MPa}$ in mature sweet cherry. Somewhat lower $\Psi_{P}^{\text {fruit }}$ has been reported for other cracking-susceptible fruit crops such as grapes [0.3 MPa (Matthews et al., 1987)], gooseberries $(0.7 \mathrm{MPa})$, black currants $(0.5 \mathrm{MPa})$, and gooseberry $\times$ black currant hybrids [Ribes nidigrolaria $\mathrm{B}$. (0.6 MPa)] (Khanal et al., 2011). All these estimates share two commonalities. First, all the $\Psi_{P}^{\text {fruit }}$ values reported are strictly apparent values of $\Psi_{P}^{\text {fruit }}$ because they were not measured directly but were calculated by a difference from measurements of wholefruit water potential and of the $\Psi_{\Pi}^{\text {fruit }}$ of the fruit's expressed juice. Second, these $\Psi_{P}^{\text {fruit }}$ values are surprisingly high. In fact, most are almost 10 times higher than the pressure in a car tire (car tires are usually inflated to $\approx 0.2 \mathrm{MPa}$ ). Given this benchmark, the fruit pressure they suggest $(\approx 2 \mathrm{MPa})$ should be seen as counterintuitive bearing in mind the soft "feel" of a sweet cherry compared with the hard feel of a car tire. If the car tire were to be overinflated to 10 times the recommended pressure (from 0.2 to $2 \mathrm{MPa}$ ), it would "feel" like steel! To our knowledge, there have been no direct measurements of $\Psi_{P}^{\text {fruit }}$ or of $\Psi_{P}^{c e l l}$ in sweet cherry fruit. In grapes, which have a similar architecture, the $\Psi_{P}^{\text {cell }}$ and $\Psi_{P}^{\text {fruit }}$ values have been quantified using pressure probes (Lang and Düring, 1990; Thomas et al., 2006, 2008) and using compression plates (Bernstein and Lustig, 1981). These techniques measure $\Psi_{P}^{\text {cell }}$ and/or $\Psi_{P}^{\text {fruit }}$ directly. The post-veraison $\Psi_{P}^{\text {fruit }}$ and $\Psi_{P}^{\text {cell }}$ values reported by 

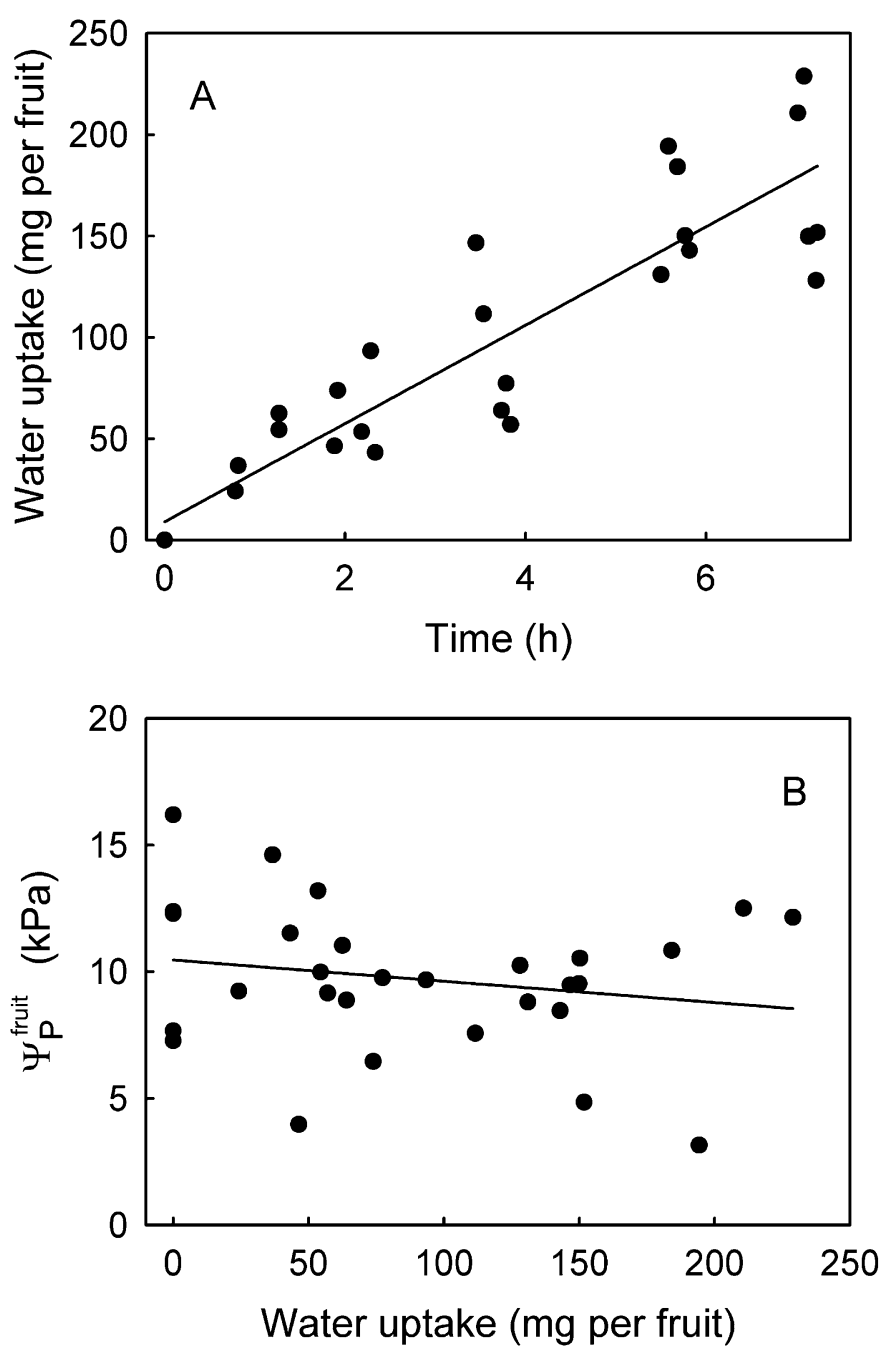

Fig. 5. (A) Time course of water uptake of mature 'Sweetheart' sweet cherry. (B). Effect of water uptake on the pressure inside the fruit $\left(\Psi_{P}^{\text {fruit }}\right)$ as determined by the fruit pressure probe (FPP). Fruit were allowed to take up water for up to $7 \mathrm{~h}$, the amount of water taken up quantified gravimetrically, and the $\Psi_{P}^{\text {fruit }}$ determined by FPP.

these authors were always lower than $0.1 \mathrm{MPa}$ at maturity (Bernstein and Lustig, 1981, 1985; Lang and Düring, 1990; Thomas et al., 2006, 2008). These values are very much lower than the indirect values referred to previously and are moreover consistent not only with the values we obtained here but also with the soft feel of the fruit. One possible reason why some indirect estimates of fruit pressure are so high could stem from confusion over the property measured by a pressure bomb (Scholander et al., 1965). A pressure bomb measures not apoplast water potential, but apoplast pressure. These two are numerically the same only when apoplast $\Psi_{\Pi}$ is close to zero. The pressure bomb is most commonly used to measure apoplast pressure in transpiring leaves. Here, this precondition is usually met and thus the common (but slightly careless) terminology has arisen where we talk of measuring leaf water potential with a pressure bomb. This being the case, some of the indirect fruit pressure estimates are probably in error.

Possible ReAsons For LOW $\Psi_{P}^{\text {cell }}$ AND $\Psi_{P}^{\text {fruit }}$. Because the cuticle is an effective barrier to either liquid- (ingress) or vaporphase (egress) water transport through the fruit surface, we
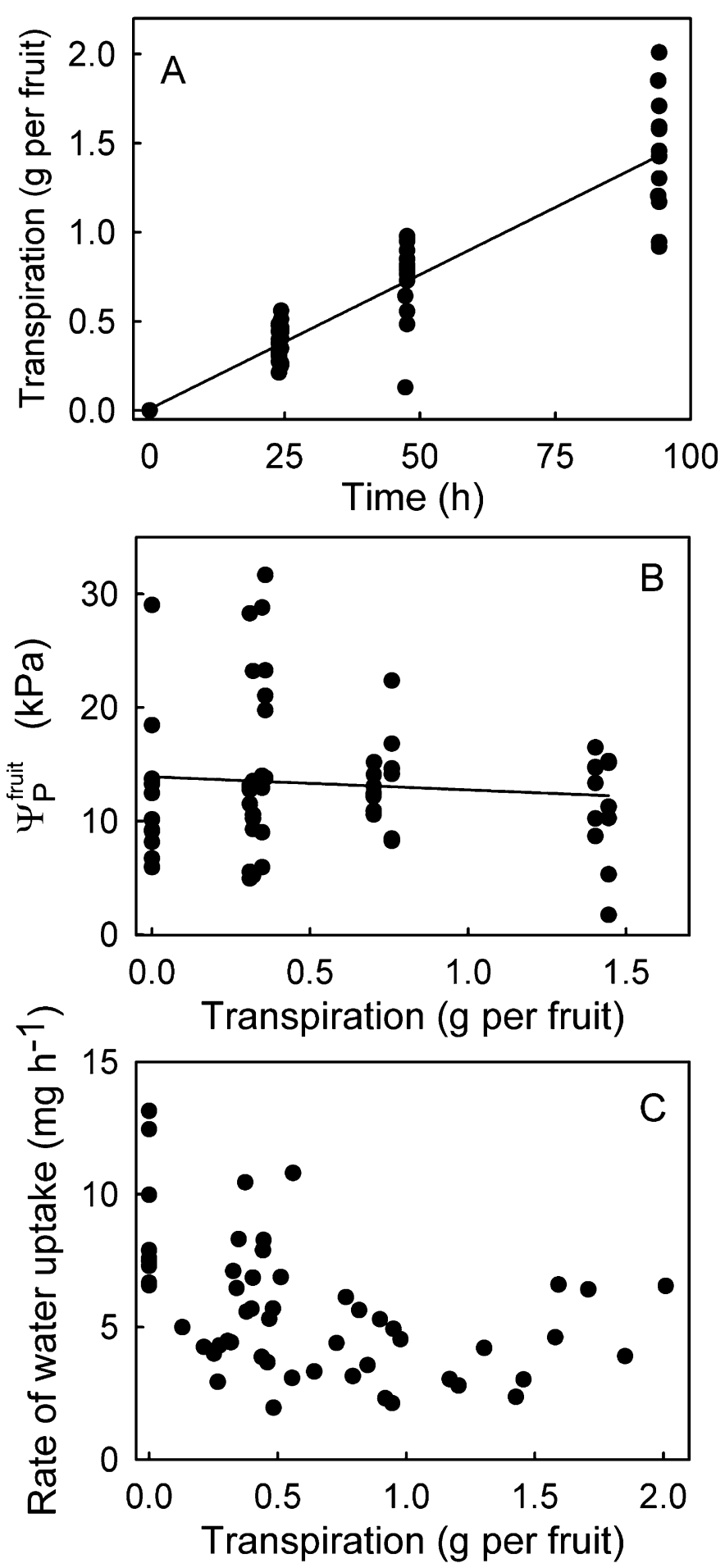

Fig. 6. (A) Time course of transpiration of mature 'Regina' sweet cherry. (B). Whole fruit pressure $\left(\Psi_{P}^{\text {fruit }}\right)$ as affected by transpiration. The $\Psi_{P}^{\text {fruit }}$ was quantified using the fruit pressure probe (FPP). (C) Relationship between the amount of water lost during transpiration and subsequent water uptake. Here, fruit were allowed to transpire and the amount of transpiration quantified gravimetrically. Subsequently, the same fruit were incubated in water and the amount of water taken up quantified gravimetrically in a water uptake assay.

expect the tissues inside the fruit and hence the fruit's apo- and symplasts to be in reasonably close water potential equilibrium, $\Psi^{\text {apoplast }}=\Psi^{\text {symplast }}$. Under these conditions, the sums of the osmotic and pressure components of the two compartments can 
be equated as $\Psi_{\Pi}^{\text {symplast }}+\Psi_{P}^{\text {symplast }}=\Psi_{\Pi}^{\text {apoplast }}+\Psi_{P}^{\text {apoplast }}$. For the large, thin-walled cells of the mesocarp, the volume fraction of the symplast very greatly exceeds that of the apoplast so the measured $\Psi_{\Pi}^{\text {fruit }}$ of the expressed juice will likely be equivalent to $\Psi_{\Pi}^{\text {symplast }}$. Because the $\Psi_{P}^{\text {cell }}$ (CPP, VPO) and the $\Psi_{P}^{\text {fruit }}$ (FPP, $\mathrm{CP})$ are very close to atmospheric pressure, we can infer that the $\Psi^{\text {fruit }}$ is numerically close to the $\Psi_{\Pi}^{\text {symplast }}$ and that $\Psi_{\Pi}^{\text {apoplast }}$ is similar to $\Psi_{\Pi}^{\text {symplast }}$. This being the case, it seems likely that osmotically active substances have accumulated in the apoplast. To our knowledge, there is no direct evidence for an accumulation of significant $\Psi_{\Pi}^{\text {apoplast }}$ in sweet cherries. However, in post-veraison grapes, solutes were shown to accumulate in the apoplast and essentially eliminate the $\Psi_{P}^{\text {cell }}$ (Matthews and Shackel, 2005; Thomas et al., 2009; Wada et al., 2008, 2009). Theoretically, such solutes may result from leakage of the symplast caused by a loss of compartmentation or decreased reflection coefficients of plasma membranes (Lang and Düring, 1991) or from rupture of plasma membranes resulting from the bursting of individual cells (Tilbrook and Tyerman, 2008). Alternatively, apoplastic solutes may result from a lack of loading of solutes that had been unloaded from the phloem into the sweet cherry apoplast as was proposed for stimulating phloem transport in the turgor-regulated phloem translocation hypothesis (Lang, 1983) or as was demonstrated for water-cored apple (Malus $\times$ domestica Borkh.) tissue (Gao et al., 2005).

LACK OF RESPONSE OF $\Psi_{P}^{\text {fruit }}$ TO WATER UPTAKE AND TRANSPIRATION. The absence of a significant effect of water uptake on $\Psi_{P}^{\text {fruit }}$ is surprising, particularly because 1) water uptakes of up to $0.2 \mathrm{~mL}$ result in significant cracking in this (M. Knoche, unpublished data) and earlier studies (Christensen, 1996; Weichert et al., 2004); and 2) based on current theories, cracking is thought to be related to increased $\Psi_{P}^{\text {fruit }}$ (Measham et al., 2009; Sekse, 1995; Sekse et al., 2005).

A reasonable explanation accounting for water uptake without an associated increase in $\Psi_{P}^{\text {fruit }}$ is that the skin suffers an increase in strain without an associated increase in stress. Recent studies by Grimm et al. $(2012,2013)$ demonstrate that the strain in the exocarp of mature sweet cherry fruit is largely reversible and is released in a time-dependent manner after excision. This behavior is referred to as viscoelasticity (Niklas, 1992; Vincent, 1990) and is a common characteristic of cellwall composites. Chanliaud et al. (2002) presented evidence that the hemicellulose fraction of the cell-wall polymers is likely responsible for viscoelasticity. In any system, it is inevitable that under conditions of increasing strain, there will be a tendency for a build up of stress. Because there was no detectable increase in $\Psi_{P}^{\text {fruit }}$ with water uptake, we must infer that stress release occurs almost instantaneously, i.e., that the stress-release processes are rapid relative to the rates of strain associated with water uptake.

The absence of a significant $\Psi_{P}^{\text {fruit }}$ would also account for the lack of a significant relationship between the rate of transpiration and that of water uptake. This inference is based on the following argument. The maximum amount of water transpired over $94 \mathrm{~h}$ averaged $\approx 1.4 \mathrm{~g}$ per fruit. This loss will have caused the osmotic concentration of the juice and, hence, the driving force for water uptake to increase by $\approx 15 \%$ (osmolality will have increased by $178 \mathrm{mmol} \cdot \mathrm{kg}^{-1}$ or $0.44 \mathrm{MPa}$ ). This driving force increase will have been offset by a fruit surface area decrease of $\approx-8.9 \%\left(-2.1 \mathrm{~cm}^{2}\right)$. We can reasonably expect that the net result of the transpirational water loss would be an increase in water uptake rate of only $4.8 \%$. With fruit:fruit variability, this change would not have been detectable in our gravimetric water transport experiments.

Comparing PRESSURe PROBE, COMPRESSION PLATE, AND WATER VAPOR OSMOMETRY FOR QUANTIFYING $\Psi_{P}^{\text {cell }}$ AND $\Psi_{P}^{\text {fruit }}$. Despite of their quite different measurement principles, the pressure values obtained using these three techniques were remarkably similar. Nevertheless, some small but consistent differences were observed that deserve comment.

The CPP and the FPP are the most widely used direct measurement techniques. Although their principles of measurement are identical, some differences are worth noting. The fine capillary tip (30 to $60 \mu \mathrm{m}$ diameter) of the CPP allows individual cells to be punctured. Thus, the CPP quantifies the pressure (relative to atmospheric pressure) of the symplast of a single cell usually defined as cell turgor (here, $\Psi_{P}^{\text {cell }}$ ). Because the epidermal and hypodermal cells of mature sweet cherries are too small (less than $50 \mu \mathrm{m}$ diameter) to be successfully punctured, measurements were restricted to the much larger cells (100 to $200 \mu \mathrm{m}$ diameter) of the outer parenchyma at depths of between 200 and $400 \mu \mathrm{m}$ below the fruit surface. In contrast, the capillary of the FPP is significantly wider at the tip (150 to $250 \mu \mathrm{m}$ diameter) and hence many of the large (100 to $200 \mu \mathrm{m}$ diameter), thin-walled cells of the outer parenchyma are ruptured. This results in a general mixing of the symplast (relatively large) and apoplast (relatively small) volumes in the vicinity of the probe aperture. The FPP measures the resultant pressure of this mixture of ruptured cells: protoplasts, cell walls, intercellular fluids. We refer to the pressure at this site as the $\Psi_{P}^{\text {fruit }}$. Based on the theory of shells (Considine and Brown, $1981)$, this $\Psi_{P}^{\text {fruit }}$ (megapascals) resulted from the stress ( $\sigma$ in Newtons per square millimeter) caused by the elastic strain of the fruit skin according to $\Psi_{P}^{\text {fruit }}=\frac{2 t \cdot \sigma}{r}$ where $\mathrm{t}$ (millimeters) represented the thickness of the structural shell and $r$ (millimeters) the radius of the sphere.

Compared with the FPP, the CP uses quite different physical principles to measure $\Psi_{P}^{\text {fruit }}$. Increasing, bilateral compressive forces are applied stepwise to the fruit and the aplanation area for each force step is quantified. In contrast to CPP and FPP, the method is much easier to operate. There are no potential artifacts such as plugging of a probe tip or leakage around the shoulder of the probe like with CPP or FPP. The $\Psi_{P}^{\text {fruit }}$ values recorded by $\mathrm{CP}$ were of the same order of magnitude as the FPP ones but were nevertheless slightly higher. The reasons for this difference are unknown. Several factors may be involved. First, $\mathrm{CP}$ tests are based on the assumption that the fruit resembles a liquid-filled vessel where the incompressible liquid inside is held under pressure by a stressed skin. Although this model may be applicable to sweet cherry fruit over long time scales (greater than $1 \mathrm{~d}$ ), it is unlikely to hold for the shorter time scales (less than $1 \mathrm{~h}$ ) in our CP experiments. Over these shorter time scales, the tissue offers some resistance to deformation thereby absorbing some of the force applied. This would result in a slight overestimation of $\Psi_{P}^{\text {fruit }}$ by the CP compared with one determined by the FPP. Second, mature sweet cherry fruit are not perfect spheres and this may be why measurements of $\Psi_{P}^{\text {fruit }}$ by CP depend to some extent on the fruit's shape and its orientation on the plate. Third, the analysis of the CP data assumes structural homogeneity of the skin, but skin extensibility and, possibly, flesh deformability of cherry fruit could well vary between regions of the fruit. For example, heterogeneity may arise from the presence of pedicel, stylar scar, suture, 
or from vascular bundles within the mesocarp. These factors may have contributed to the small deviations between the $\Psi_{P}^{\text {fruit }}$ data by CP and by FPP. However, it is important to notice that although these deviations are significant, they are also very small. So it is fair to conclude that the $\mathrm{CP}$ represents an accurate and also a relatively robust and straightforward method for determining $\Psi_{P}^{\text {fruit }}$.

The VPO method differs from all the others in that it is indirect. It yields a calculated estimate for $\Psi_{P}^{\text {cell }}$ that is obtained by difference from an evaluation of $\Psi_{\Pi}^{\text {tissue }}$ and of $\Psi^{\text {tissue }}$. On excision, sweet cherry tissue relaxes in a time-dependent manner. Grimm et al. (2012) reported a half time of relaxation for skin segments of $\approx 2.7 \mathrm{~min}$. In our experiment, the excised tissue disc was introduced within $1 \mathrm{~min}$ into the sampling chamber and equilibrated for $15 \mathrm{~min}$ before the reading was taken. During this time, the relaxation of the tissue would be essentially complete. Also, we would expect relaxation of the thin-walled parenchyma disc to be more rapid than that of the collenchymatous fruit skin segments used by Grimm et al. (2012). Consequently, any error resulting from tissue tension would have been small.

\section{Conclusions}

Our results demonstrate that $\Psi_{P}^{\text {cell }}$ and $\Psi_{P}^{\text {fruit }}$ are low in the mature fruit of sweet cherry and the other soft, crackingsusceptible drupes and berries examined here. The most likely explanation is that as the $\Psi_{\Pi}$ of the symplast decreases (becomes more negative) during ripening, there is a similar decrease in the apoplast $\Psi_{\Pi}$ resulting from a build up of apoplast solutes. The near equivalence of the $\Psi_{\Pi}$ in symplast and apoplast reduces cell and fruit turgor to near zero. Moreover, the viscoelastic properties of the cell walls and skin also help by accommodating volume and area changes (strain) at the scale both of the cell and of the fruit without significant build up of stress. The reversibility inherent in viscoelasticity allows fruit to accommodate the diurnal oscillations in fruit volume and area observed in various fruit crops (e.g., Lang, 1990; Ohta et al., 1997; Yao et al., 2000). Whereas reversibility of strain and viscoelasticity of excised exocarp segments has recently been demonstrated (Grimm et al., 2012), there is at present no experimental evidence for the presence of apoplastic solutes in sweet cherry. Such information would be needed to understand the mechanical architecture of sweet cherries and other soft, fleshy, and cracking-sensitive fruit. A better understanding of these processes is essential because, based on the results presented here, the validity of the critical turgor pressure concept to explain cracking must be questioned.

\section{Literature Cited}

Andersen, P.C. and D.G. Richardson. 1982. A rapid method to estimate fruit water status with special reference to rain cracking of sweet cherries. J. Amer. Soc. Hort. Sci. 107:441-444.

Bernstein, Z. and I. Lustig. 1981. A new method of firmness measurement of grape berries and other juice fruits. Vitis 20:15-21.

Bernstein, Z. and I. Lustig. 1985. Hydrostatic methods of measurement of firmness and turgor pressure of grape berries (Vitis vinifera L.). Sci. Hort. 25:129-136.

Beyer, M., S. Peschel, M. Knoche, and M. Knörgen. 2002. Studies on water transport through the sweet cherry fruit surface: IV. Regions of preferential uptake. HortScience 37:637-641.

Chanliaud, E., K.M. Burrows, G. Jeronomidis, and M.J. Gidley. 2002. Mechanical properties of primary plant cell wall analogues. Planta 215:989-996.
Christensen, J.V. 1996. Rain-induced cracking of sweet cherries. Its causes and prevention, p. 297-327. In: Webster, A.D. and N.E. Looney (eds.). Cherries. CAB Intl., Wallingford, UK.

Considine, J. and K. Brown. 1981. Physical aspects of fruit growthTheoretical analysis of distribution of surface growth forces in fruit in relation to cracking and splitting. Plant Physiol. 68:371-376.

Considine, J.A. and P.E. Kriedemann. 1972. Fruit splitting in grapes. Determination of the critical turgor pressure. Aust. J. Agr. Res. 23:17-24.

Gao, Z., S. Jayanty, R. Beaudry, and W. Loescher. 2005. Sorbitol transporter expression in apple sink tissues: Implications for fruit sugar accumulation and watercore development. J. Amer. Soc. Hort. Sci. 130:261-268.

Grimm, E., S. Peschel, T. Becker, and M. Knoche. 2012. Stress and strain in the sweet cherry fruit skin. J. Amer. Soc. Hort. Sci. 137:383390.

Grimm, E., S. Peschel, and M. Knoche. 2013. Mottling on sweet cherry fruit is caused by exocarp strain. J. Amer. Soc. Hort. Sci. 138:18-23. Khanal, B.P., E. Grimm, and M. Knoche. 2011. Fruit growth cuticle deposition, water uptake and fruit cracking in jostaberry, gooseberry and black currant. Sci. Hort. 128:289-296.

Knoche, M., M. Beyer, S. Peschel, B. Oparlakov, and M.J. Bukovac. 2004. Changes in strain and deposition of cuticle in developing sweet cherry fruit. Physiol. Plant. 120:667-677.

Lang, A. 1983. Turgor regulated translocation. Plant Cell Environ. 6:683-689.

Lang, A. 1990. Xylem, phloem and transpiration flows in developing apple fruits. J. Expt. Bot. 41:645-651.

Lang, A. and H. Düring. 1990. Grape berry splitting and some mechanical properties of the skin. Vitis 29:61-70.

Lang, A. and H. Düring. 1991. Partitioning control by water potential gradient: Evidence for compartmentation breakdown in grape berries. J. Expt. Bot. 42:1117-1122.

Matthews, M.A., G. Cheng, and S.A. Weinbaum. 1987. Changes in water potential and dermal extensibility during grape berry development. J. Amer. Soc. Hort. Sci. 112:314-319.

Matthews, M.A. and K.A. Shackel. 2005. Growth and water transport in fleshy fruit, p. 181-197. In: Holbrook, N.M. and M.A. Zwieniecki (eds.). Vascular transport in plants. Elsevier Academic Press, Amsterdam, The Netherlands.

Measham, P.F., S.A. Bound, A.J. Gracie, and S.J. Wilson. 2009. Incidence and type of cracking in sweet cherry (Prunus avium L.) are affected by genotype and season. Crop Pasture Sci. 60:1002-1008.

Niklas, K.J. 1992. Plant biomechanics: An engineering approach to plant form and function. Univ. Chicago Press, Chicago, IL.

Ohta, K., T. Hosoki, K. Matsumoto, M. Ohya, N. Ito, and K. Inaba. 1997. Relationships between fruit cracking and changes of fruit diameter associated with solute flow to fruit in cherry tomatoes. J. Jpn. Soc. Hort. Sci. 65:753-759.

Scholander, P.F., H.T. Hammel, E.D. Bradstreet, and E.A. Hemmingsen. 1965. Sap pressure in vascular plants. Science 148:339-346.

Sekse, L. 1995. Fruit cracking in sweet cherries (Prunus avium L.). Some physiological aspects-A mini review. Sci. Hort. 63:135-141.

Sekse, L., K.L. Bjerke, and E. Vangdal. 2005. Fruit cracking in sweet cherries-An integrated approach. Acta Hort. 667:471-474.

Steudle, E. 1993. Pressure probe techniques: Basic principles and application to studies of water and solute relations at the cell, tissue and organ level, p. 5-36. In: Smith, J.A.C. and H. Griffiths (eds.). Water deficits: Plant responses from cell to community. Bios Scientific Publishers, Oxford, UK.

Taiz, L. and E. Zeiger. 1991. Plant physiology. Benjamin/Cummings, Redwood City, CA.

Thomas, T.R., M.A. Matthews, and K.A. Shackel. 2006. Direct in situ measurement of cell turgor in grape (Vitis vinifera $\mathrm{L}$.) berries during development and in response to plant water deficits. Plant Cell Environ. 29:993-1001.

Thomas, T.R., M.A. Matthews, and K.A. Shackel. 2009. Seasonal pattern of apoplastic solute accumulation and loss of cell turgor 
during ripening of Vitis vinifera fruit under field conditions. J. Expt. Bot. 60:1773-1781.

Thomas, T.R., K.A. Shackel, and M.A. Matthews. 2008. Mesocarp cell turgor in Vitis vinifera L. berries throughout development and its relation to firmness, growth, and the onset of ripening. Planta 228:1067-1076.

Tilbrook, J. and S.D. Tyerman. 2008. Cell death in grape berries: Varietal differences linked to xylem pressure and berry weight loss. Funct. Plant Biol. 35:173-184.

Vincent, J. 1990. Structural biomaterials. Princeton Univ. Press, Princeton, NJ.

Wada, H., M.A. Matthews, and K.A. Shackel. 2009. Seasonal pattern of apoplastic solute accumulation and loss of cell turgor during ripening of Vitis vinifera fruit under field conditions. J. Expt. Bot. 60:1773-1781.

Wada, H., K.A. Shackel, and M.A. Matthews. 2008. Fruit ripening in Vitis vinifera: Apoplastic solute accumulation accounts for preveraison turgor loss in berries. Planta 227:1351-1361.

Weichert, H., C.V. Jagemann, S. Peschel, M. Knoche, D. Neumann, and W. Erfurth. 2004. Studies on water transport through the sweet cherry fruit surface: VIII. Effect of selected cations on water uptake and fruit cracking. J. Amer. Soc. Hort. Sci. 129:781788.

Yao, C., S. Moreshet, B. Aloni, and L. Karni. 2000. Effects of climatic factors and water stress on the diurnal fluctuation in diameter of bell pepper fruit. J. Hort. Sci. Biotechnol. 75:6-11. 